\title{
SLOVENIAN PRIMARY SCHOOL FOREIGN LANGUAGE TEACHERS: AN INSIGHT INTO THE TEACHING OF A FOREIGN LANGUAGE AT AN EARLY AGE ACCORDING TO CLIL
}

\begin{abstract}
Summary
The research paper presents the results of a research into the attitude of Slovenian public primary school foreign language teachers toward the teaching of the first foreign language (FL1) in the second grade according to CLIL. FL1 has been gradually introduced into a third of Slovenian primary schools as of 2014/2015 and has been taught in the second grade preferably according to CLIL. Hence, FL1 teachers have been using some variant of CLIL in their FL teaching, although some may not have been properly trained in the field. The problem arises as to whether or not the approach used in the FL1 teaching is really CLIL or some other of the previously used teaching approaches or methods. Teachers who agreed to participate in our research were kindly requested to complete the questionnaire anonymously on-line. Additionally, twelve interviews were carried out to establish the in-depth attitudes toward FL1 teaching with CLIL. We were interested to see whether the FL1 teachers' attitudes toward CLIL differed significantly regarding their age, gender, and period of sampling. Both quantitative and qualitative research methods were used in the research. The data were analysed using cross tabulations and text analysis was used for the interviews. The results show that age influences upon the choice of the teaching approach, namely, younger participants were more in favour of using CLIL as opposed to older participants; further regarding gender the analyses show that male participants tended to quit using CLIL sooner than the female participants; regarding the period of sampling the analyses show no particular influence upon the usage of CLIL.
\end{abstract} teachers.

Keywords: CLIL, early language learning, first foreign language, young language

*_tilen.smajla@gmail.com 


\section{Introduction}

The introduction of the first foreign language (FL1) as an obligatory subject in the first cycle of primary school in Slovenia has triggered several serious discussions regarding the nature and effects the teaching of foreign languages might have on young learners. The present study addresses two key issues in the area of teaching young learners, i.e. the attitudes towards FL1 teaching at an early age according to Content and Language Integrated Learning approach (CLIL) and the role of the young foreign learners' language teacher.

Foreign language teaching has received considerable attention due to its implications in the forming of attitudes towards the foreign language learning. Some renowned authors have already dealt with the topic as early as in the late 1960s and early1970s (cf. Rivers 1965; James 1969; Jakobovits 1970; Gardner and Wallace 1972). More recently, Cameron (2001, 1) claimed that teaching a foreign language to young foreign language learners is different from teaching adults or adolescents. Since the motivation to learn is an important determinant, a teachers' attitude toward learning and teaching is a relevant topic. In addition to the above-mentioned authors, the area of second language teaching attitudes has received considerable attention especially in relation to motivation and foreign language achievement (cf. Gardner 1985, 2010; Gardner and McIntyre 1993; Dörnyei 1998, 2003; Masgoret and Gardner 2003; Merisuo-Storm 2006).

FL learner's negative attitudes towards language learning can weaken their motivation and thus hinder learning, whereas positive attitudes can do quite the opposite (Merisuo-Storm 2006, 10). Thus, it is important for a teacher to look into the attitude of his or her pupils (Oxford 2001, 168). Therefore, we can state that attitudes of foreign language teachers are in fact a key issue. The worldwide trend of introducing FL1 teaching from an early age on has somehow redefined the role of the young learners' language teacher, which in the European context meant developing a model of a generalist primary school teacher with extra qualifications for teaching a foreign language (Brumen and Dagarin Fojkar 2012; Enever 2014). 


\section{Foreign language at an early age in the Republic of Slovenia}

Since FL1 was introduced in the first three-year cycle of primary schools in Slovenia, opinions over who is allowed to teach young learners have differed greatly among the policy makers. While the generalist model is recommended in most countries, Eurydice $(2012,85)$ suggests different profiles of foreign language teachers to be used across Europe. As far as the Slovene context, Brumen and Dagarin Fojkar $(2012,39)$ point out that both specialist and generalist teachers' models are used with generalist teachers who are required to get an additional qualification for teaching a foreign language up to grade 6 of primary school. See Table 1 for a detailed description of teachers' qualifications according to Eurydice (2008).

Table 1. European categories of qualified foreign language teachers (adapted from Eurydice 2008, 78).

\begin{tabular}{|l|l|}
\hline Title & Qualification description \\
\hline Generalist teacher & $\begin{array}{l}\text { Qualified for teaching of (almost) all curriculum subjects, } \\
\text { regardless of the specific training }\end{array}$ \\
\hline Specialist teacher & $\begin{array}{l}\text { Qualified for teaching of two different subjects, one of } \\
\text { them being a foreign language }\end{array}$ \\
\hline Partly specialized teacher & $\begin{array}{l}\text { Qualified for teaching of a group of at least three different } \\
\text { subjects, one or more than one being a foreign language }\end{array}$ \\
\hline Unqualified teacher & $\begin{array}{l}\text { No special definition by Eurydice. } \\
\text { Example: in Britain it can be a senior language assistant, } \\
\text { teaching foreign languages, normally a native speaker } \\
\text { with a university bachelor degree in his/her mother } \\
\text { tongue. }\end{array}$ \\
\hline
\end{tabular}

A special teacher-training course is therefore required for teaching young learners for specialist teachers in the first cycle of primary school. Three Slovenian universities have already prepared a suitable course having in mind that as of school year 2014/2015 Slovenian primary schools would start with a gradual introduction of the first foreign language in the second grade (Ministrstvo za izobraževanje, znanost in šport 2014). To cope with the inevitable shortage of suitably trained staff, schools have thought sending their foreign language teachers to the special course for the early foreign language teaching and vice versa, school managements 
have motivated their first cycle primary generalist teachers to attend the special course in early foreign language teaching. This was a necessary step, since all Slovenian primary schools were required to introduce FL1 as latest as school year 2016/2017 in the first grade.

One of the recommendations ensuing from investigating global practices of teaching English to young learners reported by Garton, Coplan and Burns (2011) would concern the development of teachers' English language proficiency and skills. The authors argue that primary school teachers who received training in English language teaching often lack confidence in their English ability, which is not necessarily the case if related to the perception of their actual or insufficient proficiency level.

\section{Teaching a foreign language according to CLIL}

Coyle, Hood and Marsh (2010) claim that CLIL is an umbrella term adopted in the mid-1990s for any activity in which a foreign language is used as a tool in the learning of a nonlanguage for it encompasses any activity in which a foreign language is used as a tool in the learning of a non-language subject in which both language and subject have a joint role (Marsh 2002, 58). Coyle, Hood and Marsh $(2010,1)$ define CLIL as a dual-focused educational approach in which an additional language is used for the learning and teaching of both content and language. The two processes, teaching and learning, are interwoven, even if the emphasis is greater on one or the other at a given time (ibid.). First and foremost, foreign language teachers should bear in mind that the core principles behind Content and Language Integrated Learning include global statements such as "all teachers are teachers of language" (The Bullock Report - Language for Life 1975, as cited in Darn 2015) to the wide-range advantages of cross-curricular bilingual teaching in statements from the Content and Language Integrated Project (CLIP) (Darn 2015). While CLIL may be the best-fit methodology for language teaching and learning in a multilingual and increasingly multicultural Europe, the literature suggests that there remains a dearth of CLIL-type materials and a lack of teacher training programmes to prepare both language and subject teachers for CLIL teaching. If carried out in the suitable manner, CLIL can prove to be an innovative 
approach with undoubted advantages (Coonan 2012, 126; Marsh, Pavón Vàzquez, and Frigols Martín 2013). The approach itself is widely known, but under different denominations - in French speaking countries the programme is called EMILE, in some other regions it is called bilingual education (Marsh 2012).

\section{Method}

\section{Problem of the research and its purpose}

FL1 was first introduced into the second grade of one third of Slovenian public elementary schools in the school year 2014/2015. The project, which was in its trial phase, was to be carried out on a national level in the school year 2016/2017. FL1 teaching ought to have been done according to CLIL approach, which was not the advised approach, although it was the designed approach to be used in FL1 teaching at an early age (Ministrstvo za izobraževanje, znanost in šport 2012). We assumed that the participants in our research had certain attitudes towards FL1 teaching according to CLIL approach, which has not been thoroughly looked into in Slovenia. To our best knowledge, no other research of attitudes regarding FL1 with CLIL has been carried out among FL1 teachers, school managements or elementary school students in the Republic of Slovenia. The purpose of our research was hence to find out whether the attitudes toward CLIL approach in FL1 teaching differ in the course of its introduction and which factors influence the change in attitudes.

\section{Research hypotheses}

H1: There are statistically significant differences in attitudes of FL1 teachers towards the CLIL approach with regard to their age.

$\mathrm{H} 2$ : There are statistically significant differences in attitudes of FL1 teachers towards the CLIL approach with regard to gender.

H3: There are differences in attitudes of FL1 teachers toward the CLIL approach with regard to the period of sampling. 
Research questions

RQ1: Do FL1 teachers' attitudes towards the CLIL approach differ regarding their age?

RQ2: Do FL1 teachers' attitudes towards the CLIL approach differ regarding their gender?

RQ3: Do FL1 teachers' attitudes towards the CLIL approach differ regarding the period of sampling?

\section{Research method}

Both quantitative and qualitative research methods have been used in the research. It was carried out among foreign language teachers in 61 Slovenian primary schools that participated in the first round of introduction of FL1 into the second grade. An on-line questionnaire was set up and the respondents were asked to fill in the questionnaire, which was anonymous. In addition, a letter was sent to these schools aiming to motivate as many schools as possible. We chose to contact those schools and ask for permission to interview their FL teachers. 12 FL1 teachers agreed to be interviewed. The quantitative data were analysed using Statistical Package for Social Sciences SPSS Version 22 (crosstabulation) and text analysis for interviews in the qualitative part of the research.

\section{Sample}

The return rate in the on-line questionnaire was 25 (51\% of FL1 teachers who started the on-line survey). $8 \%$ of males and $92 \%$ of females participated in the research. For purposes of easier analysis participants were divided into 2 age groups, group one being participants ranging from 21-40 years of age and group two participants from 41-61 years of age. Results showed $78 \%$ of the participants were in group one, $28 \%$ of the participants were in group two. See Table 2 bellow for the analysis of the level of education. 
SLOVENIAN PRIMARY SCHOOL FOREIGN LANGUAGE TEACHERS: AN INSIGHT INTO THE TEACHING OF A FOREIGN LANGUAGE AT AN EARLY AGE ACCORDING TO CLIL

Table 2. Presentation of the respondents' level of education.

\begin{tabular}{|l|c|c|}
\hline Level of education & Frequency & Valid percent \\
\hline 1 (pre-Bologna higher education) & 1 & $4 \%$ \\
\hline 2 (university education or Bologna 1st grade) & 0 & $0 \%$ \\
\hline $\begin{array}{l}3 \text { (university education or Bologna 2nd grade - the } \\
\text { so called Bologna master) }\end{array}$ & 23 & $92 \%$ \\
\hline 4 (Master of Science or PhD) & 0 & $0 \%$ \\
\hline 5 (Postgraduate Degree called Specialization) & 1 & $4 \%$ \\
\hline Total & 25 & $100 \%$ \\
\hline
\end{tabular}

Table 2 shows that the majority of the participants from the on-line research $(92 \%)$ achieved a university degree or the Bologna master, only $4 \%$ of the participants still held the pre-Bologna higher education degree, and finally, $4 \%$ of the participants held a postgraduate degree or specialization degree.

In addition to the on-line questionnaire, 12 semi-structured interviews were carried out. Interviewees were foreign language teachers from Slovenian public primary schools that were accepted for a gradual introduction of FL1 into grade 2 that took place in the school year 2014/2015. All interviewees were female teachers. All 12 participants received a university degree. See Table 3 for detailed information regarding the sample in the qualitative part of the research.

\section{Gathering of data and the research instrument}

The gathering of data took place winter 2014 (December 2014-Jauary 2015) and in summer 2015 (May-July 2015). Data was collected using a combination of quantitative and qualitative methods. As far as the qualitative data gathering is concerned the semi-structured interviews were carried out in spring 2016 (February-March 2016). They consisted of five open-ended questions. As far as the quantitative data gathering is concerned, an on-line anonymous questionnaire made out of three parts was used: a general part, open-ended questions part, and a 5-point Likert scale 
questionnaire. An adjusted instrument was used in the research of attitudes of FL teachers that was translated into Slovenian (Karavas 1993; Karavas Doukas 1996). The original instrument was a three-fold instrument, made of a questionnaire (29 items), attitude scale (24 items), and interviews. Ours was a 4-fold instrument, consisting of a 5-point Likert scale questionnaire made of 14 items, 1 general question, 6 open-ended questions as well as general demographic part consisting of two parts, one aimed to gather information about gender, age, and region of the participants, the other aimed to inquire about the level of education of the participants.

Table 3. Detailed representation of the sample (interviewees).

\begin{tabular}{|l|c|c|l|c|l|c|}
\hline & Gender & $\begin{array}{l}\text { Years in } \\
\text { service }\end{array}$ & Teacher type & $\begin{array}{c}\text { Additional } \\
\text { training in } \\
\text { FLT/EFLL }\end{array}$ & Region & $\begin{array}{c}\text { Years of } \\
\text { EFLT }\end{array}$ \\
\hline Inter. 1 & $\mathrm{F}$ & 19 & generalist & FLT & Obalno-kraška & 8 \\
\hline Inter . & $\mathrm{F}$ & 12 & generalist & FLT & Pomurje & 1 \\
\hline Inter. 3 & $\mathrm{F}$ & 26 & generalist & FLT & Podravje & 2 \\
\hline Inter. 4 & $\mathrm{F}$ & 7 & generalist & FLT & $\begin{array}{l}\text { Notranjsko- } \\
\text { kraška }\end{array}$ & 2 \\
\hline Inter. 5 & $\mathrm{F}$ & 12 & generalist & FLT & $\begin{array}{l}\text { Notranjsko- } \\
\text { kraška }\end{array}$ & 12 \\
\hline Inter. 6 & $\mathrm{F}$ & 8 & generalist & FLT & Obalno-kraška & 1 \\
\hline Inter. 7 & $\mathrm{F}$ & 10 & generalist & FLT & Podravje & 6 \\
\hline Inter. 8 & $\mathrm{F}$ & 10 & generalist & FLT & Goriška & 2 \\
\hline Inter. 9 & $\mathrm{F}$ & 13 & generalist & FLT & Goriška & 7 \\
\hline Inter. 10 & $\mathrm{F}$ & 7 & generalist & FLT & Goriška & 7 \\
\hline Inter. 11 & $\mathrm{F}$ & 10 & generalist & FLT & Gorenjska & 10 \\
\hline Inter. 12 & $\mathrm{F}$ & 17 & specialist & EFLL & Podravje & 13 \\
\hline
\end{tabular}

Inter. $=$ interviewee

$\mathrm{FLT}=$ foreign language teaching

$\mathrm{EFLL}=$ early foreign language learning

\section{Results}

At the beginning of this section we would like to present results concerning the number of participants in the on-line survey with regard to the period of sampling, since the period of sampling is one of the variables. The results are presented in the tables bellow. 
Table 4. Number of respondents in the on-line

survey regarding both periods of sampling.

\begin{tabular}{|l|c|c|}
\hline Period of sampling & Frequency & Percent \\
\hline Winter & 31 & 63.3 \\
\hline Summer & 18 & 36.7 \\
\hline Total & 49 & 100 \\
\hline
\end{tabular}

Table 4 shows that the majority of respondents engaged in the online survey in the winter period of sampling. We would like to point out that the number of primary schools that were contacted was identical in both periods of sampling, consequently the teachers, who were contacted, were the same teachers coming from the same schools in both periods of sampling.

Table 5. The results of the analysis of foreign language teachers' attitudes towards the usage of CLIL with regard to the period of sampling and age.

\begin{tabular}{|l|c|c|c|c|c|c|c|c|c|c|}
\hline & & & POS & & & Age & & & $\chi^{2}$ & $\mathrm{p}$ \\
\hline Using CLIL & $\mathrm{f}$ & $\mathrm{f} \%$ & $\mathrm{~W}$ & $\mathrm{~S}$ & Total & $21-40$ & $41-60$ & Total & .032 & .859 \\
\hline Yes & 16 & 32.6 & 10 & 6 & 16 & 8 & 1 & 9 & & \\
\hline No & 22 & 44.9 & 17 & 5 & 23 & 7 & 3 & 10 & & \\
\hline No answer & 9 & 18.4 & 4 & 5 & 9 & 2 & 3 & 5 & & \\
\hline Not specified & 2 & 4.1 & 0 & 2 & 2 & 1 & 0 & 1 & & \\
\hline Total & 49 & 100 & 31 & 8 & 49 & 18 & 7 & 25 & & \\
\hline
\end{tabular}

POS $=$ Period of sampling

$\mathrm{W}=$ winter

$\mathrm{S}=$ summer

$\chi 2=$ Pearson's chi square test

$\mathrm{p}=$ statistical significance

Judging from results presented in Table 5, the majority of the respondents or $44.9 \%$ do not teach according to CLIL, but use some other approach, be it communicative or some CLIL-derivative. Regarding the variable age we cannot claim that younger foreign language teachers seem to be keener on using CLIL than their older colleagues due to the relatively small sample, yet the tendency is slightly negative. The Pearson's $\chi^{2}$ result $(p<0.859)$ does not imply a statistical significance. Hence, we cannot confirm Hypothesis 1. 
Table 6. Respondents who quit using CLIL regarding the period of sampling and age.

\begin{tabular}{|l|l|c|c|}
\hline \multicolumn{2}{|c|}{} & \multicolumn{2}{c|}{ Quit CLIL } \\
\hline \multirow{2}{*}{ Period of sampling } & $\mathrm{W}$ & Yes & No \\
\cline { 2 - 4 } & $\mathrm{S}$ & 1 & 4 \\
\hline Total & & 0 & 6 \\
\hline \multicolumn{2}{|c|}{} & 1 & $\mathrm{~S}$ \\
\hline Quit CLIL & Y & No \\
\hline \multirow{2}{*}{ Age } & $21-40$ & 0 & 8 \\
\cline { 2 - 4 } & $41-60$ & 1 & 2 \\
\hline Total & & 1 & 10 \\
\hline
\end{tabular}

POS $=$ Period of sampling

$\mathrm{W}=$ winter

$\mathrm{S}=$ summer

Regarding the respondents who chose to quit using CLIL Table 6 shows the following result: the majority of the participants or 10 chose to continue using CLIL, although the negative trend was on the increase in the final part of the school year. Regarding the participants' age, Table 6 shows that the majority or 10 participants who answered this question did not use CLIL in FL1 teaching, 2 of them were younger FL1 teachers and 8 older FL1 teachers. There was a slight change regarding the use of CLIL between the older and younger FL1 teachers, yet the numbers are too small for us to be able to claim a general trend. Moreover, the period of sampling does not seem to have affected greatly the choice of FL1 teachers whether or not to keep or quit using CLIL approach. Hence, we are not able to confirm Hypothesis 3.

The following part investigates the attitudes of foreign language teachers towards the usage of CLIL regarding their gender. Table 7 shows the number of participants who attended some sort of CLIL training.

Table 7. Number of respondents who attended CLIL course according to gender.

\begin{tabular}{|l|c|c|c|}
\hline & \multicolumn{2}{|c|}{ GENDER } & \\
\hline CLIL seminar & M & F & TOTAL \\
\hline yes & 0 & 9 & 9 \\
\hline no & 2 & 8 & 10 \\
\hline No answer & 0 & 5 & 5 \\
\hline Not specified & 0 & 1 & 1 \\
\hline Total & 2 & 23 & 25 \\
\hline
\end{tabular}

$\mathrm{M}=$ male teachers

$\mathrm{F}=$ female teachers 
Table 7 presents the following results: no male participants received training in CLIL methodology, although that did not seem to have affected their attitudes toward CLIL; 39.1\% of female participants on the other hand received some kind of CLIL training as opposed to $34.7 \%$ who received no CLIL training.

The Table 8 bellow presents the results of the analysis of the respondents' attitudes towards using CLIL regarding their gender.

Table 8. Results of the analysis of the respondents' attitudes toward the use of CLIL with regard to gender.

\begin{tabular}{|c|c|c|c|c|c|c|c|c|c|}
\hline & \multicolumn{2}{|c|}{ GENDER } & & & & & & $\chi^{2}$ & $\mathrm{p}$ \\
\hline $\begin{array}{l}\text { TEACH BY } \\
\text { CLIL }\end{array}$ & M & $\mathrm{F}$ & TOTAL & $\begin{array}{l}\text { QUIT } \\
\text { CLIL }\end{array}$ & $\mathrm{F}$ & M & TOTAL & 25.000 & .297 \\
\hline YES & 2 & 20 & 22 & & 1 & 0 & 1 & & \\
\hline $\mathrm{NO}$ & 1 & 2 & 3 & & 9 & 1 & 10 & & \\
\hline
\end{tabular}

$\mathrm{M}=$ male teachers

$\mathrm{F}=$ female teachers

$\chi^{2}=$ Pearson's chi square test

$\mathrm{p}=$ statistical significance

Table 8 shows that two male participants chose to teach using CLIL, although no male participant received any sort of CLIL training (see Table 7 above); 20 female participants or $90 \%$ of those who answered the question taught using CLIL and had a positive attitude towards it. Interestingly, only one female participant or $4.3 \%$ decided to stop using CLIL towards the end of the school year. The number of male participants is too small to allow for conclusions. The Pearson's $\chi^{2}$ result $(p<0.297)$ does not imply a statistically significant difference in attitudes towards the quitting of CLIL, hence we could not confirm Hypothesis 2.

The following part of the paper presents the results of the qualitative research that was carried out in the period February-March 2016. The interviewees were asked the following five questions:

1. What is your attitude towards the teaching and learning of a foreign language at an early age?

2. What is your attitude towards CLIL?

3. How does the attitude towards the teaching and learning of a foreign language at an early age and towards CLIL change re- 
garding the gender, the years in service, and regarding the basic education of the teacher?

4. Do the attitudes regarding CLIL and the teaching and learning of a foreign language at an early age change in the course of its implementation?

5. Is using CLIL useful in foreign language teaching?

For the purposes of the paper we shall discard questions 1,4 , and 5 and shall present the findings of the questions 2 and 3.

Regarding the attitudes towards CLIL the interviewees seemed to have shared very similar opinions, for their responses have been almost identical. The only exception was the interviewee 12 with 17 years in service whose opinion on CLIL was highly positive. She emphasised that she "had personally been using this approach in the first cycle of primary school for 12 years, even prior to the actual official introduction and the results were obvious". She added that "the advantage of this approach is that the students do not get the feeling that FL is a separate subject, rather a part of their timetable". Besides, the interviewee pointed out one element that was somewhat overlooked by the other interviewees, namely that good results had been achieved especially with children with a different background and social environment (Roma, immigrants), since "CLIL lessons originated in a sense of equality, for in order to understand the teacher, everybody had to put in the same amount of effort". The so called "leveller" effect of CLIL has already been mentioned in Coyle, Hood and Marsh $(2010,18)$. This is specially the case in classes, where migrant children may have limited access to the majority language of the environment (ibid.).

Interviewee 1 was introduced to CLIL approximately in 1997. She claimed that only some elements of CLIL could really be considered for FL teaching. Eight other interviewees shared this opinion, they claimed they had all either already heard of CLIL or had been using some elements of it. Interviewee 1 with 19 years in service sustained that "some elements of CLIL (points out language shower) had been very effective, for they kept the students motivated"; besides she thought "important to learn the classroom language". Interviewee 2 with 12 years in service also claimed that "CLIL is partly effective": it took her two months to teach the students the general instructions and she "wasn't able to cover the curriculum". 
Among the reasons for which the interviewees only use some elements of CLIL, the following problems and challenges were highlighted: timeconsuming negotiations with class teachers, organization issues. Seven out of twelve interviewees pointed out these issues, which is a disturbing fact.

Six out of twelve interviewees stated CLIL to be to some extent useful. For instance, interviewee 11 with 10 years in service claimed, "using CLIL demanded a lot of adjusting and long hours of cooperation with class teachers, joint planning, and exchange of materials...". Similarly, interviewee 8 with 10 years in service said, "from the organization point of view, it is hard work". Negotiating the workload with the class teacher is what interviewee 7 with 10 years in service pointed out as well. She sustained "CLIL to be ok, but I soon found out that regardless the good cooperation with the class teacher I was slacking off. Besides, there were organization issues, payment problems...". Organization issues (cooperation with class teachers) made interviewee 4 with 7 years in service believe that "CLIL is more appropriate in the second or even in the third cycle of primary school (6th to 9th grade), when students have acquired enough foreign language competences". She also claimed that she "wouldn't be successful in using CLIL in the first cycle of primary school, the reason being Slovenian language not being the mother tongue or home language of some students, so we should not overexpose them to foreign languages in other subjects, like Maths or Science".

Six interviewees out of 12 stated that they preferred working using modules or cross-curricular links. All six also found CLIL theoretically fine, yet there seems to be some challenge practicing CLIL. Similarly, interviewees $8,9,11$, and 12 claimed that "working in modules was easier, besides it was far less stressful using cross-curricular links". They merely used some elements of CLIL, mostly community making, communication, and content (three C's of the 4/5 C CLIL matrix). Moving away from CLIL is what interviewee 11 with 10 years in service reported, when she stated having taught the FL only using CLIL in the first year of the gradual introduction of FL1 into the first cycle, but now (2015) teaches using themebased approach and matrix. Once more, interviewee 12 with 17 years in service claimed: "during my lessons I mostly use cross-curricular links, merely with Maths, Science and Nature, Sport, and Music". It is the pre- 
viously mentioned subjects that are mostly taught using CLIL, which is frequently used in the third cycle of primary and secondary schools (Ricci Garotti 2008, 47-49).

\section{Discussion}

As far as the variable period of sampling (POS) is concerned, the results of our research show a higher number of respondents who stated having attended CLIL training in the winter period. Our analyses show that POS had almost no influence over the attitude towards CLIL, although the results showed a slight tendency to keep using CLIL in the second POS (June 2015) compared to the Winter POS. Further, the results also show that more respondents attended a CLIL course of other form of CLIL training in the winter POS.

Regarding the variable age, the results show that younger respondents seemed to have been keener on using CLIL. Younger respondents were also more persistent in using CLIL throughout the entire school year. In contrast to that, older respondents seemed to have quit using CLIL sooner. As far as the variable gender is concerned the results show female respondents to be more in favour of teaching by CLIL than males, males also quit using CLIL far sooner as compared to females. The small sample does not allow for a more general assumption, but is indicative. The results obtained in our research could be linked to the so-called affective factor of CLIL, which can be either negative or positive (Coonan 2014a, 21; Coonan 2014b, 82). The positive effect manifested in the way in which the student perceives his/her experience with FL as a possibility of a boost of his/her development. CLIL could bring about a feeling of success, a pleasant surprise, a feeling of achievement after a successfully overcome challenge. On the other hand CLIL could also cause feelings of failure, especially when the student was unable to understand the meaning of a text or listening exercise. This can lead to frustrations (due to cognitive overload), and even to disinclination or actual rejection. Similarly, the same could be claimed for FL1 teachers, who were challenged with CLIL and its features at the beginning of the school year 2014/2015.

Interestingly, only one interviewee uses CLIL with all its elements. It is the interviewee number 12 coming from the north-eastern part of Slovenia. 
Further, CLIL, or rather some elements of it, are partly used by seven interviewees coming from all 12 statistical regions in Slovenia. Our analyses also show that four interviewees do not use CLIL, be it due to the lack of knowledge (interviewee 10) or to the so-called CLIL-fright (interviewees 4, 6, and 8). What united this group is that two interviewees originate from the Goriško region, two from Notranjsko-kraška region, both situated in the west or midwest part of Slovenia. Furthermore, they all share a relatively low number of years in service ( 8 on the average), which is in contrast to other interviewees, who stated using CLIL only partly (17 years on the average).

\section{Conclusion}

In conclusion, we can say that the research has raised several issues about the teachers' attitudes towards the teaching of a foreign language per CLIL. It had been suggested that attitudes vary according to gender, age, the period of sampling. The results of the research have revealed differences in the usage of the CLIL approach with regard to the participants' gender. To be precise, male participants in the on-line survey seemed to be less keen on engaging into CLIL or even attending a CLIL course, they were less interested in continuing using CLIL in the first place. Further, attitudes are not static, they change over time, and primary school foreign language teachers might change their attitude if offered proper training in the proper period. The results from the qualitative part of the research also show a division as to preferring or not preferring CLIL based on regional origin of interviewees. More effort and energy should therefore be invested into a more levelled CLIL training and not concentrate it in the CLIL stronghold in the northeast part of Slovenia, where CLIL has a long tradition and a strong theoretical background.

Nevertheless, CLIL remains "a successful model" (Lohman 2009). Most of the participants agreed that, for its power is proved by theory and practice abroad, and by the statements of the interviewed teachers. It cannot be denied that CLIL effectively develops students' foreign language competences, at the same time fostering intercultural understanding, thus paving the way for a multicultural and multilingual Europe. 


\section{References}

Brumen, Mihaela, and Mateja Dagarin Fojkar. 2012. "Teacher development in Slovenia for teaching foreign languages at the primary level." CEPS Journal 2 (3): 27-53.

Cameron, Lynne. 2001. Teaching Languages to Young Learners. Cambridge: Cambridge University Press.

Coonan, Carmel Mary 2012. "The foreign language curriculum and CLIL." Synergies Italie 8: 117-128.

Coonan, Mary C. 2014a. "I principi di base del CLIL." In Fare CLIL. Strumenti per l'insegnamento integrato di lingua e disciplina nella scuola secondaria, edited by Paolo E. Balboni and Carmel M. Coonan, 22-24. Venezia: Università Cá Foscari, Loescher Editore.

Coonan, Mary C. 2014b. "Un ampliamento di prospettiva: il CLIL di lingua straniera." In L'italiano L1 come lingua dello studio, edited by PaoloE. Balboni and M: Mezzadri, 79-87. Venezia: Università Cá Foscari, Loescher Editore.

Coyle, Do, Phillip Hood, and David Marsh. 2010. CLIL - Content and Language Integrated Learning. Cambridge: Cambridge University Press.

Darn, Steve. 2015. CLIL: A Lesson framework. British Council. Accessed 8. 3. 2017 https://www.teachingenglish.org.uk/article/clil-a-lesson-framework

Dörnyei, Zoltán. 1998. "Motivation in second and foreign language learning." Language Teaching 31 (3): 117135.

Dörnyei, Zoltán. 2003. "Attitudes, orientations, and motivations in language learning: Advances in Theory, Research, and Applications." Language Learning 53 (S1): 3-32.

Enever, Janet. 2014. "Primary English teacher education in Europe." ELT Journal 68 (3): 231-242.

Eurydice. 2008. Key Data on Teaching Languages at School in Europe. Brussels: Education, Audiovisual and Culture Executive Agency. Accessed 8. 8. $2013 \mathrm{http} / /$ eacea.ec.europa.eu/about/eurydice/documents/KDL2008 EN.pdf

Eurydice. 2012. Key Data on Teaching Languages at School in Europe. Brussels: EACEA P9 Eurydice. 
Gardner, Robert C. 1985. Social psychology and second language learning. The role of attitudes and motivation. London: Edward Arnold.

Gardner, Robert C. 2010. Motivation and Second Language Acquisition: The Socio-Educational Model. New York: Peter Lang.

Gardner, Robert C., and Peter D. MacIntyre. 1993. "A student's contributions to second-language learning. Part II: Affective variables." Language Teaching 26 (1): 1-11.

Gardner, Robert C., and Wallace E. Lambert. 1972. Attitudes and motivation in second-language learning. Newbury House Publishers: University of Michigan.

Garton, Sue, Fiona Copland, and Anne Burns. 2011. Investigating global practices in teaching English to young learners. London: British Council.

James, Leon. 1969. Measuring foreign language aptitude and attitude. Hawaii: University of Hawaii.

Jakobovits, Leon A. 1970. Foreign Language Learning: A Psycholinguistic Analysis of the Issues. Newbury House Publishers: University of Michigan.

Karavas, Evdokia. 1993. "English Language Teachers in the Greek Secondary School: A study of their classroom practices and their attitudes towards methodological and materials innovation." Unpublished PhD diss., University of Warwick. Accessed 4. 9. 2014 http://wrap.warwick.ac.uk/36100/1/WRAP_THESIS_Karavas_1993.pdf

Karavas-Doukas, Evdokia. 1996. "Using attitude scales to investigate teachers' attitudes to the communicative aproach." ELT Journal 50 (3): 187-198.

Lohmann, Christa. 2009. "Bilingualer Unterricht-ein Erfolgsmodell." Praxis Englisch 6: 46-48.

Marsh, David. 2002. CLIL/EMILE- The European Dimension: Actions, Trends and Foresight Potential. European Commission: Public Services Contract DG EAC.

Marsh, David. 2012. Content and Language Integrated Learning (CLIL). A Development Trajectory. Córdoba: Servicio de Publicaciones de la Universidad de Córdoba. 
Marsh, David, Victor Pavón Vázques, and María Jesús Frigols Martín. 2013. The Higher Education Languages Landscape: Ensuring Quality in English Language Degree Programmes. Valencia: Valencian International University.

Merisuo-Storm, Tuula. 2006. "Pupils' attitudes towards foreign-language learning and the development of literacy skills in bilingual education." Teaching and Teacher Education 23 (2): 226-235.

Ministrstvo za izobraževanje, znanost in šport. [Ministry of Education]. 2012. Učni načrt za tuji jezik v prvem vzgojno-izobraževalnem obdobju osnoven šole. Accessed 13. 5. 2014 http://www.mizs.gov.si/fileadmin/mizs.gov.si/pageuploads/podrocje/os/prenovljeni_UN/Tuji_ jezij_v_prvem_VI_obdobju.pdf.

Ministrstvo za izobraževanje, znanost in šport. [Ministry of Education]. 2014. Sklep o izboru osnovnih šol, ki se v šolskem letu 2014/2015 vključijo v postopno uvajanje prvega tujega jezika v 2. razred osnovne šole. Ac-

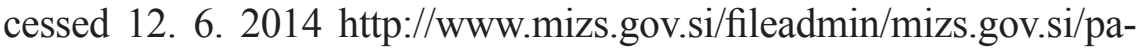
geuploads/Aktualno/Sklep_prvi_tuji_jezik_2r_OS_29_5_14_pop.pdf

Oxford, Rebecca. L. 2001. "Language learning strategies." In The Cambidge Guide to Teaching English to Speakers of Other Languages, edited by Ronald Carter and David Nunan, 166-172. Cambridge: Cambridge University Press.

Ricci Garotti, Federica. 2008. "Lernziele, Lehrziele und Methode im CLIL Unterricht: Eine Frage der Kohärenz." In CLIL e l'apprendimento delle lingue. Le sfide del nuovo ambiente di apprendimento, edited by $\mathrm{C}$. Mary Coonan. 37-58. Venezia: Università Ca' Foscari, Dipartimento di Scienze del Linguaggio.

Rivers, Wilga R. 1965. The Psychologist and the Foreign-Language Teacher. Chicago: University of Chicago Press. 


\title{
Tilen Smajla
}

\section{NASTAVNICI STRANOG JEZIKA U SLOVENAČKIM OSNOVNIM ŠKOLAMA: IZLET U NASTAVU STRANIH JEZIKA PREMA CLIL-U NA RANOM UZRASTU}

\begin{abstract}
Sažetak
Predmet ovog rada čine rezultati istraživanja kojim se proučavaju stavovi nastavnika stranih jezika državnih osnovnih škola u Sloveniji prema nastavi prvog stranog jezika u drugom razredu u skladu sa CLIL nastavom. Prvi strani jezik (JS1) se postepeno uvodi u trećinu slovenačkih osnovnih škola od 2014/2015. godine, a podučava se od drugog razreda uz preporuku da se sledi CLIL metod. Usled toga, nastavnici stranog jezika u svom radu koriste neki oblik CLIL-a, iako nisu svi dobili odgovarajuću obuku na ovom polju. Postavlja se pitanje da li se metod rada u nastavi prvog stranog jezika zaista može okarakterisati kao CLIL ili je u pitanju neki prethodno korišćen nastavni pristup. Nastavnici koji su prihvatili da učestvuju u ovom istraživanju su popunili anonimni onlajn upitnik. Povrh toga, 12 nastavnika je prihvatilo da učestvuje u intervjuu kako bi se utvrdila njihova duboka uverenja po pitanju nastave JS1 u skladu sa CLIL-om. Zanimalo nas je da li postoje razlike u stavovima nastavnika prema CLIL nastavi koje se mogu dovesti u vezu sa uzrastom, polom ili periodom uzorkovanja. $U$ analizi podataka smo koristili kvantitativne i kvalitativne metode, te smo primenili metodu krostabulacije u analizi podataka iz upitnika i tekstualnu analizu za podatke iz intervjua. Rezultati ukazuju da uzrast utiče na izbor nastavnog pristupa i da mlađi učesnici pokazuju veću naklonost prema primeni CLIL-a; u pogledu pola, pokazuje se da nastavnici češće napuštaju CLIL metod u odnosu na ženske učesnice; konačno, po pitanju perioda uzorkovanja, rezultati ne ukazuju na značajne razlike.
\end{abstract} nog jezika.

Ključne reči: CLIL, rano učenje stranih jezika, prvi strani jezik, nastavnici stra- 